\title{
Healthy goats naturally devoid of prion protein
}

\author{
Sylvie L Benestad ${ }^{1 *}$, Lars Austb $\varnothing^{2}$, Michael A Tranulis², Arild Espenes ${ }^{2}$ and Ingrid Olsaker ${ }^{2}$
}

\begin{abstract}
Prion diseases such as scrapie in small ruminants, bovine spongiform encephalopathy (BSE) in cattle and Creutzfeldt-Jakob disease (CJD) in man, are fatal neurodegenerative disorders. These diseases result from the accumulation of misfolded conformers of the host-encoded prion protein (PrP) in the central nervous system. To date naturally-occurring PrP free animals have not been reported. Here we describe healthy non-transgenic animals, Norwegian Dairy Goats, lacking prion protein due to a nonsense mutation early in the gene. These animals are predicted to be resistant to prion disease and will be valuable for research and for production of prion-free products.
\end{abstract}

\section{Introduction, methods and results}

Transmissible spongiform encephalopathies (TSE) or prion diseases such as Creutzfeldt-Jakob disease (CJD) in man, bovine spongiform encephalopathy (BSE) in cattle, and scrapie in sheep and goats are invariably fatal diseases. These diseases may be inherited (mutations in the prion protein gene), sporadic (unknown cause) or acquired (transmission of infectious agent). They are characterized by the accumulation of conformational isoforms of the normal cellular prion protein $(\operatorname{PrP})$ in the central nervous system [1]. According to the "protein-only" hypothesis, the partly protease-resistant, misfolded PrP, designated $\operatorname{PrP}^{\mathrm{Sc}}$, is the disease agent [2]. Prion diseases are entirely dependent on endogenous $\operatorname{PrP}$ expression. For instance, PrP gene knockout mice are resistant to prion disease [3], and further studies of transgenic mice have shown that the level of PrP expression is inversely correlated with the incubation time $[4,5]$. In addition, knockdown of the PrP expression by RNAi rescues early neuronal dysfunction and prolongs survival time in mice with prion disease [6].

As with sheep, goats are susceptible to both classical [7-11] and atypical [10,12-14] scrapie. One goat has also been identified as infected with BSE [15]. Classical scrapie in goat has been reported in the USA, Canada and many European countries, and its prevalence is particularly high in Cyprus (accounting for $85 \%$ of all cases in the EU between 2002 and 2007) [10]. As described in many other species, the goat $\operatorname{PrP}$ gene $(P R N P)$ is

\footnotetext{
* Correspondence: sylvie.benestad@vetinst.no

${ }^{1}$ Norwegian Veterinary Institute, P.O.Box 750, Sentrum, Oslo 0106, Norway Full list of author information is available at the end of the article
}

polymorphic and some variants have been associated with resistance to the disease $[10,11,16-18]$.

The present study is based on the discovery, in the indigenous goat breed Norwegian Dairy Goat originating from the north-European Landrace, of a new variant of the PRNP displaying a premature stop codon. Additional goats were subsequently screened for $P R N P$ polymorphisms and one goat homozygous for the new variant was analysed for the presence of PrP. Animal experiments described in this paper have been subjected to stringent ethical evaluation and were carried out in compliance with institutional and national regulations.

Genomic DNA was extracted from brain or blood samples using DNeasy 96 blood and tissue kit (Qiagen) according to the suppliers' protocol. A fragment covering the coding region of the goat PRNP was amplified by PCR with M13 tailed primers GoatF1: M13-21-CAGT CATTCATTATGCTGCAGACTT (this work) and BilG2R: M13rev-CTATCCTACTATGAGAAAAATGAG [19] and analysed by sequencing with Big Dye Primer chemistry (Applied Biosystems, Foster City, USA).

The genetic survey of the Norwegian Dairy Goat population revealed the presence of the naturally occurring nonsense mutation in the PRNP at a surprisingly high allele frequency $(11 \%, n=192$, comprising samples of unrelated animals from several flocks and random brain samples collected as part of the Norwegian scrapie surveillance programme). The mutation was located in codon $32\left({ }_{32}\right.$ Stop) terminating the PrP synthesis, leaving only seven amino acids of the mature protein (Figure 1). A subsequent search among the offspring of heterozygous animals identified two homozygous ${ }_{32}$ Stop goats 


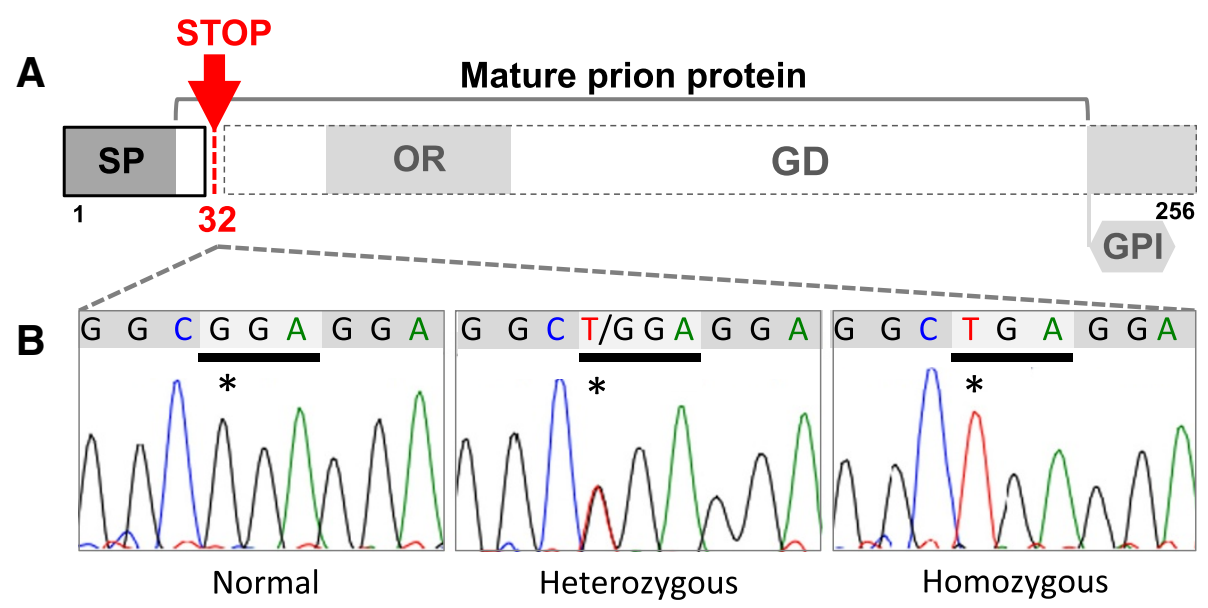

Figure 1 Graphical overview of the prion protein structure. Panel A: Goat PrP with structural domains: signal peptide (SP), five octapeptide repeats (OR), globular domain (GD) and glycophosphatidylinositol-anchor (GPI). Panel B: Sequences of the goat PRNP-region with the polymorphic base (stars).

(twins born in March 2009). One goat was sacrificed at 30 months of age and the other is currently 3.5 years old (October 2012) and remains alive in a research herd. The PRNP sequence of the sacrificed goat has been submitted to GenBank (Acc. no KC145281). Both goats have given birth to healthy kids (twice and three times, respectively) and none of them have shown any abnormal behaviour or other characteristics distinct from their flock-mates. The sacrificed goat was subjected to a routine clinical and neurological examination, then euthanized and necropsied. No abnormalities were noted.

To determine the presence or absence of PrP, goat brains were analysed by Western blotting (WB) in two separate laboratories with different protocols and by Enzyme-Linked Immunosorbent Assay (ELISA). In laboratory 1, slightly modified ELISA (TeSeE and TeSeE Sheep and Goat, Bio-Rad, Marnes-La-Coquette, France) and WB tests (TeSeE Bio-Rad) were used on the brain homogenates as recommended by the producers. Since the goal was to evaluate the presence of normal $\operatorname{PrP}$ and not only protease-resistant $\mathrm{PrP}^{\mathrm{Sc}}$, proteinase $\mathrm{K}(\mathrm{PK})$ hydrolysis of the samples was omitted, except in the negative control (sample 8 in Figure 2). In laboratory 2, the following WB method was used. Brain samples were homogenized at $4^{\circ} \mathrm{C}$ by a Dounce all-glass homogenizer in lysis buffer (LB) containing Tris-HCl pH 7.4, $150 \mathrm{mM}$ $\mathrm{NaCl}, 0.5 \%(\mathrm{w} / \mathrm{v})$ Triton X-100, $0.5 \%$ sodium deoxycholate, $1 \mathrm{mM}$ EDTA and proteinase inhibitor tablets (Roche, Applied Science, Indianapolis, USA). Samples were centrifuged at $1000 \times \mathrm{g}$ for $10 \mathrm{~min}$ to remove debris. Prior to SDS electrophoresis samples were boiled for $5 \mathrm{~min}$ in $4 \times$ SDS-samples buffer (Invitrogen, Oslo, Norway), supplemented with a reducing agent and centrifuged at $13000 \times \mathrm{g}$ for $5 \mathrm{~min}$. Samples were run on $12 \%$ precast polyacrylamide gels (Bio-Rad) with Tris MOPS as

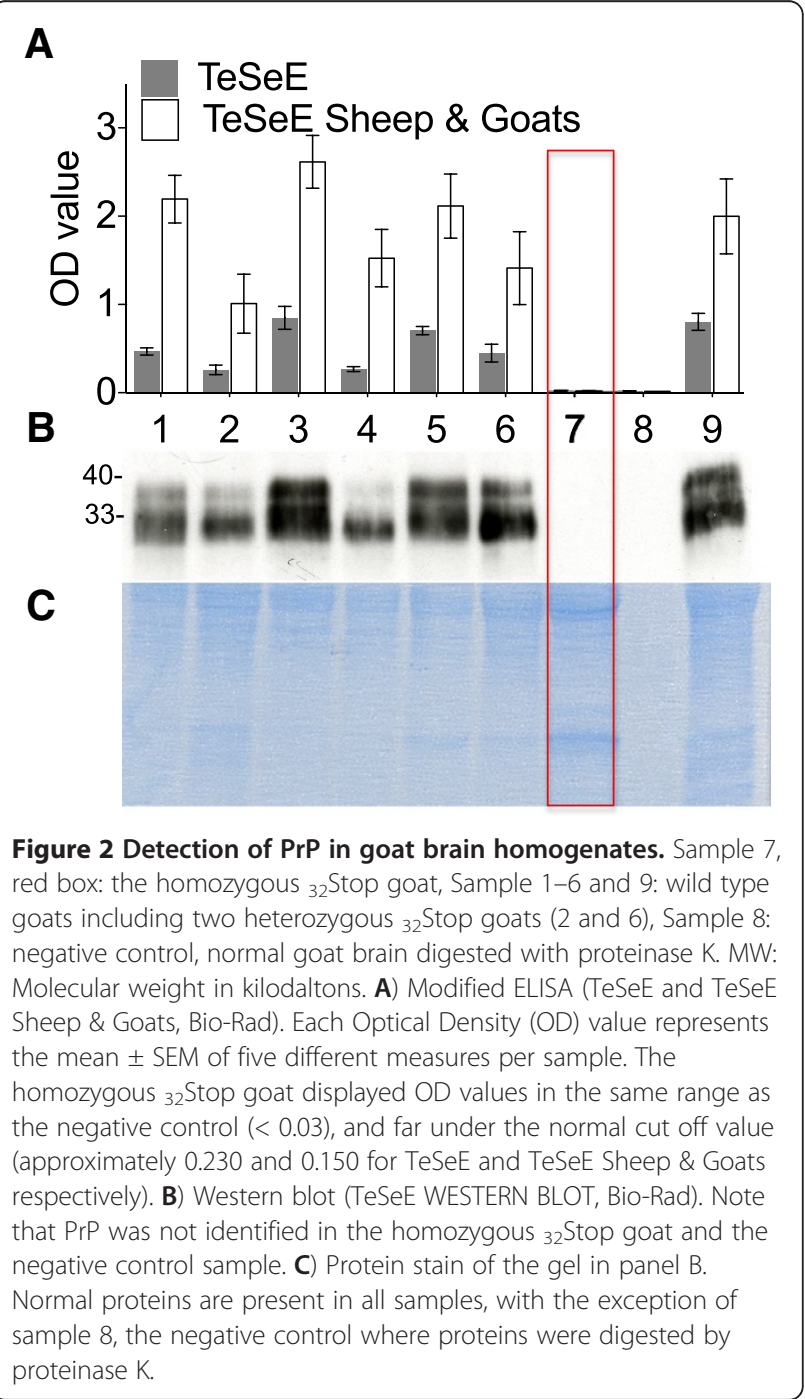


running buffer and transferred to polyvinylidene fluoride membranes by a semi-dry blotter. Membranes were blocked for $1 \mathrm{~h}$ in $5 \%$ fat-free dry milk dissolved in Tris buffered saline (TBS), prior to incubation overnight at $4^{\circ} \mathrm{C}$ with primary antibodies SAF32 (SPI-Bio, Pas-Du-Lac, France) or P4 (R-Biopharm, Darmstadt, Germany) at a concentration of $0.04 \mu \mathrm{g} / \mathrm{mL}$. Secondary antibody (goat anti-mouse) labelled with alkaline phosphatase (GE Healthcare, Little Chalfont, Buckinghamshire, UK) was used to visualize bands with a fluorescence imager (Typhoon 9200, GE Healthcare) after incubation with the ALP substrate (ECFTM, Western blotting reagent pack, GE Healthcare). As internal controls, total proteins were stained in gel with Gel Code ${ }^{\mathrm{TM}}$ Blue Safe Protein Stain (Thermo Scientific, Oslo, Norway) or with Biosafe Coomassie (Bio-Rad) in laboratory 1 and 2 respectively, as described by the manufacturers.

As an expected consequence of the early stop codon in the gene, PrP could not be detected in the homozygous ${ }_{32}$ Stop animal by any of the methods, whereas it was clearly demonstrated in all the control goats (Figures 2 and 3).

\section{Discussion}

Whilst experimental production of $\operatorname{PrP}$ gene knockouts of cattle [20] and goats [21,22] has been described, this is the first description of apparently healthy nontransgenic animals lacking $\operatorname{PrP}$ due to a naturally-

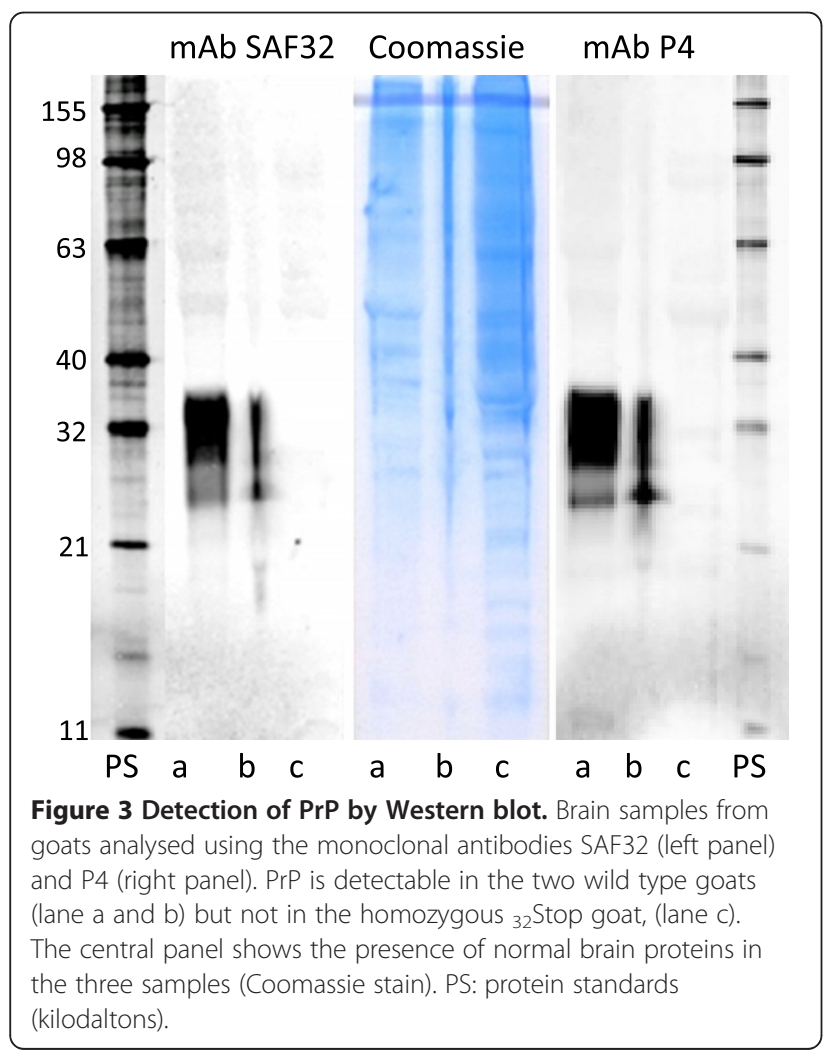

occurring mutation. Whether the ${ }_{32}$ Stop haplotype is unique to Norwegian Dairy Goats is not known. Several PrP polymorphisms have been described in goats $[10,11,17]$, but only one animal heterozygous for a nonsense mutation late in the goat PRNP, at codon 163, has been reported [11].

The ${ }_{32}$ Stop goats are unique natural tools for investigating how the $\operatorname{PrP}$ may be involved in both physiological and pathological processes. PrP is a cell surface protein largely expressed within the nervous system and is highly conserved across mammalian species. However, the natural function of the protein remains elusive. Similar to transgenic PrP gene knockout animals $[1,20,21]$, the identified goats homozygous for the ${ }_{32}$ Stop haplotype lack PrP, yet are viable and appear normal. This suggests that the protein is not involved in vital physiological processes or that its absence can be compensated for by other mechanisms. In disease-related processes $\operatorname{PrP}$ might be both positively and negatively involved. Studies of transgenic animals suggest that PrP has a role in tissue repair and protection against cellular stress $[1,23]$. Recent reports also indicate that $\operatorname{PrP}$ is involved in mediating $\mathrm{A} \beta$-induced cytotoxicity in Alzheimer's disease [24-26].

In conclusion, this is the first description of naturallyoccurring mammals lacking PrP. Goats lacking PrP differ from the valuable PrP knockout mice in many aspects and might provide a supplementary model for investigating the function of the protein. Additionally, goats resistant to prion disease will be valuable not only for breeding but also for production of prion-free materials.

Competing interests

The authors declare that they have no competing interests.

\section{Authors' contributions}

All the authors contributed to the general interpretation of the data and the writing of the manuscript. In addition, SLB designed the experiments and supervised the ELISA and Western blot tests. LA designed the experiments, interpreted the data, performed and interpret the sequencing and genetic analyses and designed the figures. MAT supervised the Western blot tests. AE participated in the collection of the material. IO discovered the stop mutation, designed the experiments, supervised and interpreted the genetic analyses. All authors read and approved the final manuscript.

\section{Acknowledgements}

We thank Agnes Klouman and the staff at the Animal Production Experimental Centre and Thor Blichfeldt and the staff at the Norwegian Association of Sheep and Goat Breeders for providing blood and DNA samples for genotyping of goats and Torleiv Løken, Department of Production Animal Sciences, Norwegian School of Veterinary Science for the clinical assessment. We are grateful to Torfinn Moldal and Magne Kaldhusdal, Norwegian Veterinary Institute, for assistance with the necropsy, the laboratory staff at the Norwegian Veterinary Institute and the Norwegian School of Veterinary Science for performing the protein analyses and Simon Hardy and Alison Coulthard for critical reading of the manuscript.

\section{Author details}

${ }^{1}$ Norwegian Veterinary Institute, P.O.Box 750, Sentrum, Oslo 0106, Norway. ${ }^{2}$ The Norwegian School of Veterinary Science, P.O.Box 8146 Dep, Oslo 0033, Norway. 
Received: 4 October 2012 Accepted: 23 November 2012

Published: 18 December 2012

\section{References}

1. Aguzzi A, Baumann F, Bremer J: The prion's elusive reason for being. Annu Rev Neurosci 2008, 31:439-477.

2. Prusiner SB: Prions. Proc Natl Acad Sci U S A 1998, 95:13363-13383.

3. Büeler $H$, Aguzzi A, Sailer A, Greiner RA, Autenried P, Aguet M, Weissmann C: Mice devoid of PrP are resistant to scrapie. Cell 1993, 73:1339-1347.

4. Arsac JN, Betemps D, Morignat E, Feraudet C, Bencsik A, Aubert D, Grassi J, Baron T: Transmissibility of atypical scrapie in ovine transgenic mice: major effects of host prion protein expression and donor prion genotype. PLoS One 2009, 4:e7300.

5. Weissmann C, Flechsig E: PrP knock-out and PrP transgenic mice in prion research. Br Med Bull 2003, 66:43-60.

6. White MD, Farmer M, Mirabile I, Brandner S, Collinge J, Mallucci GR: Single treatment with RNAi against prion protein rescues early neuronal dysfunction and prolongs survival in mice with prion disease. Proc Natl Acad Sci U S A 2008, 105:10238-10243.

7. Bouzalas IG, Dovas Cl, Banos G, Papanastasopoulou M, Kritas S, Oevermann A, Papakostaki D, Evangelia C, Papadopoulos O, Seuberlich T, Koptopoulos G: Caprine PRNP polymorphisms at codons 171, 211, 222 and 240 in a Greek herd and their association with classical scrapie. J Gen Virol 2010, 91:1629-1634

8. Colussi S, Vaccari G, Rasero R, Ponti AM, Ru G, Sacchi P, Caramelli M, Agrimi $U$, Acutis PL: Prospects for applying breeding for resistance to control scrapie in goats: The current situation in Italy. Small Ruminant Res 2010, 88:97-101.

9. Fragkiadaki EG, Vaccari G, Ekateriniadou LV, Agrimi U, Giadinis ND, Chiappini $B$, Esposito E, Conte M, Nonno R: PRNP genetic variability and molecular typing of natural goat scrapie isolates in a high number of infected flocks. Vet Res 2011, 42:104. doi:110.1186/1297-9716-1142-1104.

10. Vaccari $G$, Panagiotidis $C H$, Acin C, Peletto S, Barillet F, Acutis P, Bossers A, Langeveld J, van Keulen L, Sklaviadis T, Badiola JJ, Andréoletti O, Groschup $\mathrm{MH}$, Agrimi U, Foster J, Goldmann W: State-of-the-art review of goat TSE in the European Union, with special emphasis on PRNP genetics and epidemiology. Vet Res 2009, 40:48.

11. Papasavva-Stylianou P, Windl $O$, Saunders G, Mavrikiou P, Toumazos P, Kakoyiannis C: PrP gene polymorphisms in Cyprus goats and their association with resistance or susceptibility to natural scrapie. Vet J 2011, 187:245-250.

12. Seuberlich T, Botteron C, Benestad SL, Brunisholz H, Wyss R, Kihm U, Schwermer H, Friess M, Nicolier A, Heim D, Zurbriggen A: Atypical scrapie in a Swiss goat and implications for transmissible spongiform encephalopathy surveillance. J Vet Diagn Invest 2007, 19:2-8.

13. Le Dur $A$, Béringue $V$, Andréoletti $O$, Reine $F$, Lai TL, Baron T, Bratberg $B$, Vilotte $J$, Sarradin P, Benestad SL, Laude H: A newly identified type of scrapie agent can naturally infect sheep with resistant PrP genotypes. Proc Natl Acad Sci U S A 2005, 102:16031-16036.

14. Tranulis MA, Benestad SL, Baron T, Kretzschmar H: Atypical Prion Diseases in Humans and Animals. In Prion Proteins. Volume 305. Edited by Tatzelt J.; 2011:23-50 [Houk KN, Hunter CA, Lehn J-M, Ley SV, Olivucci M, Thiem J, Trost BM, Venturi M, Vogel P, Wong C-H, et al. (Series Editor): Topics in Current Chemistry].

15. Eloit M, Adjou K, Coulpier M, Fontaine JJ, Hamel R, Lilin T, Messiaen S, Andréoletti $O$, Baron T, Bencsik A, Biacabe AG, Béringue $V$, Laude $H$, Le Dur A, Vilotte JL, Comoy E, Deslys JP, Grassi J, Simon S, Lantier F, Sarradin P: BSE agent signatures in a goat. Vet Rec 2005, 156:523-524.

16. Goldmann W: PrP genetics in ruminant transmissible spongiform encephalopathies. Vet Res 2008, 39:30.

17. Goldmann W, Ryan K, Stewart P, Parnham D, Xicohtencatl R, Fernandez N, Saunders G, Windl O, Gonzalez L, Bossers A, Foster J: Caprine prion gene polymorphisms are associated with decreased incidence of classical scrapie in goat herds in the United Kingdom. Vet Res 2011, 42:110.

18. Acutis PL, Bossers A, Priem J, Riina MV, Peletto S, Mazza M, Casalone C, Forloni G, Ru G, Caramelli M: Identification of prion protein gene polymorphisms in goats from Italian scrapie outbreaks. J Gen Virol 2006, 87:1029-1033.

19. Billinis C, Panagiotidis CH, Psychas V, Argyroudis S, Nicolaou A, Leontides S, Papadopoulos O, Sklaviadis T: Prion protein gene polymorphisms in natural goat scrapie. J Gen Virol 2002, 83:713-721.
20. Richt JA, Kasinathan P, Hamir AN, Castilla J, Sathiyaseelan T, Vargas F, Sathiyaseelan J, Wu H, Matsushita H, Koster J, Kato S, Ishida I, Soto C, Robl JM, Kuroiwa Y: Production of cattle lacking prion protein. Nat Biotechnol 2007, 25:132-138.

21. Yu GH, Chen JQ, Xu YY, Zhu CH, Yu HQ, Liu SG, Sha HY, Chen J, Xu XJ, Wu $Y B$, Zhang A, Ma J, Cheng G: Generation of goats lacking prion protein. Mol Reprod Dev 2009, 76:3.

22. Zhu CH, Li B, Yu GH, Chen JQ, Yu HQ, Chen J, Xu XJ, Wu YB, Zhang AM, Cheng GX: Production of Prnp(-/-) goats by gene targeting in adult fibroblasts. Transgenic Res 2009, 18:163-171.

23. Biasini E, Turnbaugh JA, Unterberger U, Harris DA: Prion protein at the crossroads of physiology and disease. Trends Neurosci 2012, 35:92-103.

24. Laurén J, Gimbel DA, Nygaard HB, Gilbert JW, Strittmatter SM: Cellular prion protein mediates impairment of synaptic plasticity by amyloid-beta oligomers. Nature 2009, 457:1128-1132.

25. Gunther EC, Strittmatter SM: Beta-amyloid oligomers and cellular prion protein in Alzheimer's disease. J Mol Med (Berl) 2010, 88:331-338.

26. Resenberger UK, Harmeier A, Woerner AC, Goodman JL, Muller V, Krishnan R, Vabulas RM, Kretzschmar HA, Lindquist S, Hartl FU, Hartl FU, Multhaup G, Winklhofer KF, Tatzelt J: The cellular prion protein mediates neurotoxic signalling of beta-sheet-rich conformers independent of prion replication. EMBO J 2011, 30:2057-2070.

doi:10.1186/1297-9716-43-87

Cite this article as: Benestad et al:: Healthy goats naturally devoid of prion protein. Veterinary Research 2012 43:87.

\section{Submit your next manuscript to BioMed Central and take full advantage of:}

- Convenient online submission

- Thorough peer review

- No space constraints or color figure charges

- Immediate publication on acceptance

- Inclusion in PubMed, CAS, Scopus and Google Scholar

- Research which is freely available for redistribution

Submit your manuscript at www.biomedcentral.com/submit
C) Biomed Central 